\title{
Thermogenic Methane with Secondary Alteration in Gases Released from Terrestrial Mud Volcanoes
}

\author{
Ryoichi Nakada and Yoshio Takahashi \\ Additional information is available at the end of the chapter
}

http://dx.doi.org/10.5772/48232

\section{Introduction}

Mud volcanoes are surface expressions of mud accompanied by water and gas originated from deep underground. They are found all over the world. The locations of mud volcanoes resemble magmatic volcanoes, that is, they are concentrated in areas of compressional tectonic settings such as accretionary complexes and subduction zones (Dimitrov, 2002, 2003; Kholodov, 2002; Kopf, 2002). Recent developments in seismic exploration and seafloor imaging have led to the discovery of mud volcanoes not only onshore, but also offshore. The fact that mud volcanoes are found along the compressional area suggests that eruptions are related to the occurrence of volcanic and earthquake activity. Mud extrusion is a phenomenon wherein fluid-rich, fine-grained sediments accompanying the gases ascend within a lithologic succession through conduits from pressurized reservoirs because of their buoyancy. The factors controlling the occurrence of mud volcanoes are considered to be (i) recent tectonic activity, particularly in a compressional regime; (ii) rapid loading of rocks due to fast sedimentation, accretion, or overthrusting; (iii) active hydrocarbon generation; and (iv) existence of thick, fine-grained, soft sediments deep in the sedimentary succession (Dimitrov, 2002). The main factor in mud volcano formation is considered to be a gravitative instability in low-density sediments below high-density rocks induced by fast sedimentation.

The major differences between mud volcano and normal (magmatic) volcano are as follows: (i) mud volcano only releases, as suggested by its name, mud associated with water, whereas magmatic volcano releases ash and high-temperature lava; and (ii) most of the gases released from the former are methane $\left(\mathrm{CH}_{4}\right)$, whereas the latter releases $\mathrm{CO}_{2}$ and $\mathrm{N}_{2}$, except for water vapor. With regard to difference (i), one may think that the mud volcano is 
not serious as a natural disaster. On the contrary, in Indonesia for example, more than 30,000 people lost their homes due to the eruption of mud (Mazzini et al., 2007). The eruption of an enormous amount of mud $\left(170,000 \mathrm{~m}^{3}\right.$ per day at the maximum) with the temperature close to $100{ }^{\circ} \mathrm{C}$ buried the Sidoarjo village in Northeast Java (Mazzini et al., 2007). Thus, it is important to understand the eruption mechanism from the view of the disaster caused by the eruption. Difference (ii) is also important, considering that $\mathrm{CH}_{4}$ has a larger global warming potential than $\mathrm{CO}_{2}$ (IPCC, 2001). According to the IPCC report (2001), the global warming potential of $\mathrm{CH}_{4}$ is 62 times higher than that of $\mathrm{CO}_{2}$ in 20 years and 23 times higher in 100 years. The reported $\mathrm{CH}_{4}$ concentration released from mud volcanoes all over the world shows that $\mathrm{CH}_{4}$ dominates more than $90 \%$ for most mud volcanoes (Table 1 ). Furthermore, even if mud volcanoes are in the quiescent period, they constantly release gases into the atmosphere. Considering that magmatic volcanoes are not active in the quiescent period, the consecutive release of $\mathrm{CH}_{4}$ from mud volcanoes is potentially an important problem. Therefore, understanding the source, abundance, and cause of $\mathrm{CH}_{4}$ release from mud volcanoes is necessary to evaluate the global warming and potential resource as energy.

Both the concentration and $\mathrm{CH}_{4}$ flux from mud volcanoes to the atmosphere are important. Thus far, several estimates for global emission have been done, including $10.3 \mathrm{Tg} \mathrm{y}^{-1}$ to 12.6 $\mathrm{Tg}^{-1}$ (Dimitrov, 2002), $5 \mathrm{Tg}^{-1}$ to $10 \mathrm{Tg}^{-1}$ (Etiope and Klusman, 2002), $5 \mathrm{Tg} \mathrm{y}^{-1}$ (Dimitrov, 2003), and $6 \mathrm{Tg}^{-1}$ to $9 \mathrm{Tg}^{-1}$ (Etiope and Milkov, 2004). The estimates include several assumptions that can have large uncertainty in their flux estimation because it is almost impossible to determine the quantity of $\mathrm{CH}_{4}$ released from each mud volcano on Earth. More recently, it has also been reported that gases from mud volcanoes not only originate from visible bubbling in the crater of mud volcanoes but also from soils around mud volcanoes. For example, Etiope et al. (2011) performed flux measurements from soils around mud volcanoes in Japan and showed that total output from soils is comparable with that from vents in the mud volcanoes. Their calculation suggests that global $\mathrm{CH}_{4}$ flux from mud volcanoes is between 10 and $20 \mathrm{Tg} \mathrm{y}^{-1}$ (Etiope et al., 2011). These estimates mean that mud volcanoes represent an important natural source of atmospheric $\mathrm{CH}_{4}$ considered in global greenhouse gas emission inventories.

Understanding the origin of $\mathrm{CH}_{4}$, namely, microbial origin from acetate fermentation, microbial from carbonate reduction, thermogenic, and inorganic, provides information on the process and environment responsible for its generation. The interpretation of the origins of gas is generally based on its stable carbon and hydrogen isotopes $\left(\delta^{13} \mathrm{C}\right.$ and $\delta \mathrm{D}$, respectively), and on the chemical composition of its gaseous alkanes $\left(\mathrm{C}_{1}-\mathrm{C}_{4}\right.$; methane, ethane, propane, and butane). In particular, identifying the gas source is accomplished by plotting the stable carbon isotope ratio of $C_{1}\left(\delta^{13} C_{1}\right)$ versus the light gas composition (Bernard et al., 1978), and the $\delta^{13} \mathrm{C}_{1}$ versus $\delta \mathrm{D}_{1}$ (Schoell, 1983). Post-genetic alterations that can affect isotopic and molecular composition of gas should also be considered. The processes include (i) aerobic and anaerobic microbial oxidation of $\mathrm{CH}_{4}$, (ii) abiogenic oxidation, (iii) isotopic fractionation by diffusion, (iv) molecular fractionation by advection, (v) gas mixing, and (vi) anaerobic biodegradation of petroleum and secondary 
methanogenesis. In this respect, both the chemical and isotopic compositions of hydrocarbons and of $\mathrm{CO}_{2}$ can be useful. In this chapter, we attempt to improve our understanding of the origin of gases released from terrestrial mud volcanoes and seepages by summarizing published data. Further knowledge will allow researchers to use seepage gases as a tracer for hydrocarbon reservoirs and as an indicator of geodynamic processes, hazards, and importance in global changes.

\section{Database}

The database used in this chapter includes all terrestrial mud volcanoes and other seeps for which all the following parameters are reported: $\mathrm{CH}_{4}$ stable isotopes $\left(\delta^{13} \mathrm{C}_{1}\right.$ and $\left.\delta \mathrm{D}_{1}\right)$, compositional ratio of hydrocarbons $\left[\mathrm{C}_{1} /\left(\mathrm{C}_{2}+\mathrm{C}_{3}\right)\right]$, and concentration and stable carbon isotope ratio of $\mathrm{CO}_{2}$. The data which satisfy these restrictions are listed in Table 1. From more than 200 data, only 27 data from five countries consisted of all five parameters: 14 mud volcanoes from Azerbaijan, 7 from China, 1 from Georgia, 2 from Japan, and 3 from Turkmenistan; all other data lacked at least one parameter (Valyaev et al., 1985; Etiope et al., 2011; Nakada et al., 2011). Numerous studies have reported on at least one of the parameters above and/or the data of gases collected from the same mud volcanoes in different periods. However, the discussion should be performed using all the parameters above reported in one study, because (i) gases released from mud volcanoes have a complicated history, including secondary alterations, and (ii) compositions and stable isotope ratio can be fluctuated with time even in the same vent. Meanwhile, data from peats, recent sediments in freshwater environments, anthropogenically induced seeps from coal mines, coal-bed $\mathrm{CH}_{4}$ production, and submarine mud volcanoes are not considered.

\section{Results and discussion}

\subsection{The "Bernard" and "Schoell" diagrams}

All the data listed in Table 1 are plotted in the "Bernard" and "Schoell" diagrams, namely, $\delta^{13} C_{1}$ versus $C_{1} /\left(C_{2}+C_{3}\right)$ (Bernard et al., 1978; Faber and Stahl, 1984), and $\delta^{13} C_{1}$ versus $\delta D_{1}$ (Schoell, 1983). The former plot, which is widely used for the discrimination of thermogenic and microbial $C_{1}$, was originally developed by Bernard et al. (1978) through their analysis of hydrocarbons from Texas shelf and slop sediments. In 1984, Faber and Stahl collected sediment samples from the North Sea and modified the Bernard plot by adding the maturation trends of type II and type III kerogen. Figure 1 shows that all the gases released from mud volcanoes in China and Japan fall within or close to the thermogenic field. One of three data in Turkmenistan also falls within the thermogenic field, while two data from Turkmenistan and Georgia are in the intermediate region of the thermogenic and microbial fields. The rest of the data, all from Azerbaijan and one-third from Turkmenistan, fall in the region $\mathrm{A}$, an ambiguous sector above the thermogenic field and right to the microbial. Gases from mud volcanoes do not appear to originate from microbial activities. However, gases 
from mud volcanoes in Azerbaijan, Italy, Papua New Guinea, and Russia (Taman Peninsula) fall in the microbial area (Valyaev et al., 1985; Baylis et al., 1997; Etiope et al., 2007). The data listed in Table 1 are selected ones that show all five parameters described in the previous section. Hence, the data lacking in other parameters, such as $\delta \mathrm{D}_{1}$ or $\delta^{13} \mathrm{C}_{\mathrm{CO} 2}$, are not considered in the present work. Then, it should be noted that not all the gases released from mud volcanoes are of thermogenic origin.

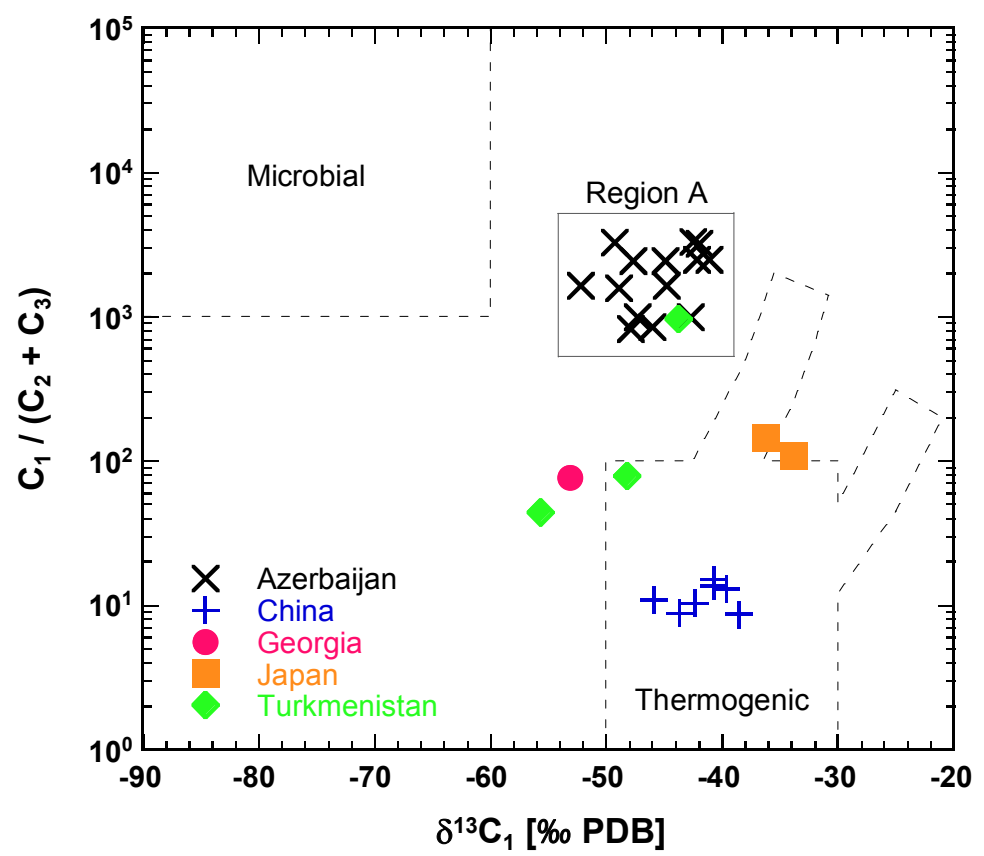

Figure 1. Carbon isotope ratio of $\mathrm{CH}_{4}$ vs. hydrocarbon molecular composition diagram (Bernard plot; Bernard et al., 1978).

The "Schoell" plot, developed by Schoell (1983) through a summary of the genetic characterization of natural gases from several basins and areas including Gulf of Mexico, German Molasse, and Vienna (references therein), also shows that the data summarized here do not fall in the microbial field (Fig. 2). Likewise, no data are plotted in the dry thermogenic field $\left(\mathrm{T}_{\mathrm{D}}\right)$. Most of the data fall in the thermogenic field associated with oil or the mixed field. The gases collected in Japan were plotted in the thermogenic field with condensate. Similar to the discussion for the Bernard diagram, the data selected in this work do not cover all the reported data on gases released from mud volcanoes. Actually, gases released from mud volcanoes in Papua New Guinea and Italy fall in the microbial field (Baylis et al., 1997; Etiope et al., 2007). However, until now, any combination of $\delta^{13} C_{1}$ and $\delta \mathrm{D}_{1}$ is not reported for the gas samples that fall on the dry thermogenic area released from mud volcano, though gases from water seeps and dry seeps sometimes fall on the dry thermogenic field (Etiope et al., 2006; 2007, Greber et al., 1997). 


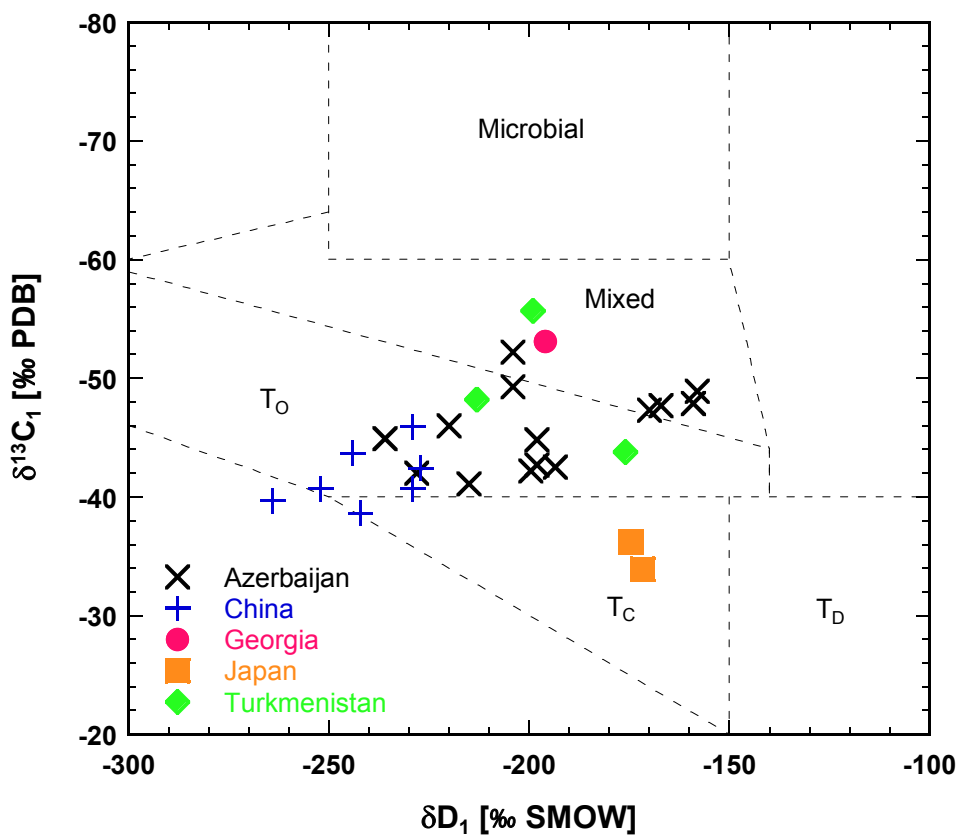

Figure 2. Carbon and hydrogen isotope diagram of $\mathrm{CH}_{4}$ (Schoell plot; Schoell, 1983); To: thermogenic with oil; Tc: thermogenic with condensate; $\mathrm{T}_{\mathrm{D}}$ : dry thermogenic.

The above figures suggest that thermogenic hydrocarbons are the main component of gases released from mud volcanoes. Considering that about half the gases from Azerbaijan fall in the thermogenic field in the Schoell plot, the reason gases plotted in region A in the Bernard diagram may be due to the fact that mixing between thermogenic and microbial or compositional ratio of hydrocarbons changed during post-genetic alteration. Considering $\delta^{13} C_{1}$ values alone, gases from Azerbaijan can be regarded as thermogenic, whereas Bernard ratios, namely, $C_{1} /\left(C_{2}+C_{3}\right)$, are in the range of microbial origin. Therefore, it can be natural to consider that the data indicate mixing of the gases with two origins. When combining the origins, however, both Bernard ratios and $\delta^{13} \mathrm{C}_{1}$ values are high enough to assume mixing between thermogenic and microbial, because the mixing trend generally tracks high $\delta^{13} \mathrm{C}_{1}$ value with low Bernard ratio to low $\delta^{13} \mathrm{C}_{1}$ value with high Bernard ratio and vise versa. This empirical rule suggests that gases from Georgia and one-third from Turkmenistan are regarded as tracking the mixing trend. On the other hand, gases from Azerbaijan and another one-third from Turkmenistan are not tracking the mixing trend, suggesting that the gases plotted in region $\mathrm{A}$ are not due to the mixing of thermogenic and microbial components. The data fall in region $\mathrm{A}$ in the Bernard diagram, therefore indicating postgenetic alteration such as (i) aerobic and anaerobic microbial oxidation of $\mathrm{CH}_{4}$, (ii) abiogenic oxidation, and (iii) anaerobic biodegradation of petroleum and secondary methanogenesis. In this respect, discussion using only isotope and compositional ratios of hydrocarbon is not sufficient; $\mathrm{CO}_{2}$ data provide useful information. 


\subsection{Large variation in $\delta^{13} \mathrm{CCO}_{2}$ from mud volcanoes}

In contrast to the $\delta^{13} \mathrm{C}_{1}$ values, $\delta^{13} \mathrm{C} \mathrm{CO}_{2}$ from mud volcanoes show a large variation, from $36.9 \%$ o to $+29.8 \%$ o (Table 1 ). Furthermore, the $\delta^{13} \mathrm{C} \mathrm{CO} 2$ values of the gases from Azerbaijan and China, which were plotted on a narrow range in the Bernard diagram, varied to a large degree. The $\delta^{13} \mathrm{C}_{1}$ values of Azerbaijan show a variation of $11.1 \%$ o (from $-52.2 \%$ o to $-41.1 \%$ ), whereas the variation of $\delta^{13} \mathrm{CCO} 2$ values is $51 \%$ (from $-36.9 \%$ o to $+14.1 \%$ ). Similar to Azerbaijan, gases from seven mud volcanoes in China show a small variation in $\delta^{13} \mathrm{C}_{1}(7.3 \%$, from $-45.9 \%$ o to $-38.6 \%$ o $)$ and a large variation in $\delta^{13} \mathrm{CCO} 2(41.3 \%$, from $-11.5 \%$ o to $+29.8 \%$ o). Besides the data selected there, similar characteristics also present in other reported data of gas released from mud volcanoes. Seven mud volcanoes in Georgia have a variation of $14.4 \%$ in $\delta^{13} \mathrm{C}_{1}$ values and a $28.7 \%$ variation of $\delta^{13} \mathrm{CCO}_{2}$ (Valyaev et al., 1985). Six vents of a mud volcano in Italy have a range of $\delta^{13} C_{1}$ in $4.3 \%$ with $29.1 \%$ variation of $\delta^{13} C_{\text {CO2 }}$ values (Favara et al., 2001). Thirteen mud volcanoes with 20 reported isotopic ratios in Russia (Taman Peninsula) show a variation of $31.3 \%$ in $\delta^{13} \mathrm{C}_{1}$ and a variation of $41.9 \%$ in $\delta^{13} \mathrm{CCO}_{2}$ (Valyaev et al., 1985; Lavrushin et al., 1996). Twelve mud volcanoes with 15 vents in Trinidad display a variation of $21.6 \%$ in $\delta^{13} \mathrm{C}_{1}$ and a $32.4 \%$ o variation in $\delta^{13} \mathrm{CCO} 2$ (Deville et al., 2003). Turkmenistan, with six available data of mud volcanoes, shows a variation of $12.5 \%$ in $\delta^{13} \mathrm{C}_{1}$ with $32.1 \%$ variation in $\delta^{13} \mathrm{CCO}_{2}$ (Valyaev et al., 1985). Eleven reported data from Ukraine show a $16.8 \%$ o variation in $\delta^{13} \mathrm{C}_{1}$ and a $40.9 \%$ o variation in $\delta^{13} \mathrm{CCO}_{\mathrm{CO}}$ (Valyaev et al., 1985). Seven mud volcanoes in Taiwan, in contrast, display a variation of $27.3 \%$ o in $\delta^{13} C_{1}$ with $17.3 \%$ in $\delta^{13} \mathrm{CCO} 2$ (Etiope et al., 2009). These facts clearly indicate that terrestrial mud volcanoes show a large variation in the isotopic ratio of $\mathrm{CO}_{2}$, though most of their $\delta^{13} \mathrm{C}_{1}$ values are within a thermogenic range.

In general, the $\delta^{13} \mathrm{CCO} 2$ value ranges from $-25 \%$ to $-5 \%$ for natural thermogenic and/or kerogen decarboxylation (Jenden et al., 1993; Kotarba, 2001; Hosgormez et al., 2008). In addition, Jenden et al. (1993) suggested that the upper limit of $\delta^{13} \mathrm{CCO}_{2}$ value due to the alteration of marine carbonates is $+5 \%$. Therefore, $\mathrm{CO}_{2}$ released from mud volcanoes with $\delta^{13} \mathrm{C} \mathrm{CO} 2$ value above that threshold can be called ${ }^{13} \mathrm{C}$-enriched $\mathrm{CO}_{2}$. Surprisingly, 14 mud volcanoes in the 28 listed in Table 1 release ${ }^{13} \mathrm{C}$-enriched $\mathrm{CO}_{2}$. Considering the 134 mud volcanoes described in the previous paragraph (data not shown), 66 (49\%) of them show the ${ }^{13} \mathrm{C}$-enriched value.

Before assessing the relationship between ${ }^{13} \mathrm{C}$-enriched $\mathrm{CO}_{2}$ and composition and isotopes of carbon in hydrocarbon gas, it is necessary to note that a large variability of the $\delta^{13} \mathrm{CCO} 2$ value can be found within a mud volcano, both in space (gas samples from different vents) and in time (same vents analyzed in different time). For example, according to Nakada et al. (2011), four mud volcanoes (sites 1-4) are located very close to one another. The chemical compositions of mud and water, as well as relative abundances and stable isotopes of various hydrocarbons, are very similar. In particular, sites 2 to 4 are located within a $500 \mathrm{~m}$ distance, suggesting that their reservoir can be the same. Among these sites, however, only a gas released from site 2 has ${ }^{13} \mathrm{C}$-enriched $\mathrm{CO}_{2}\left(+16.2 \%\right.$ ), whereas $\mathrm{CO}_{2}$ from sites 1 and 4 are within a range of kerogen decarboxylation, $-8.0 \%$ and $-11.5 \%$, respectively (gases from site 


\begin{tabular}{|c|c|c|c|c|c|c|}
\hline Name & $\delta^{13} \mathrm{C}_{1}$ & $\delta \mathrm{D}_{1}$ & $\delta^{13} \mathrm{CCO}_{2}$ & $\mathrm{CH}_{4}(\%)$ & $\mathrm{CO}_{2}(\%)$ & $\mathrm{C}_{1} /\left(\mathrm{C}_{2}+\mathrm{C}_{3}\right)$ Reference \\
\hline \multicolumn{7}{|l|}{ Azerbaijan } \\
\hline Airantekyan & -44.9 & -236 & +13.9 & 96.9 & 3.04 & 2423 Valyaev et al. (1985) \\
\hline Akhtarma Pashaly & -47.9 & -159 & -7.2 & 99.1 & 0.68 & 825 Valyaev et al. (1985) \\
\hline Chukhuroglybozy & -41.1 & -215 & +1.7 & 99.5 & 0.42 & 2488 Valyaev et al. (1985) \\
\hline Dashgil & -42.2 & -200 & -6.4 & 99.0 & 0.93 & 2476 Valyaev et al. (1985) \\
\hline Galmas & -47.7 & -167 & +13.7 & 97.4 & 2.06 & 2435 Valyaev et al. (1985) \\
\hline Goturlyg & -42.7 & -198 & -15.4 & 98.9 & 0.99 & 989 Valyaev et al. (1985) \\
\hline Gyrlykh & -49.3 & -204 & +0.6 & 98.4 & 1.54 & 3280 Valyaev et al. (1985) \\
\hline Inchabel & -48.9 & -158 & -30.9 & 94.4 & 5.53 & 1573 Valyaev et al. (1985) \\
\hline Kichik Kharami & -52.2 & -204 & +0.4 & 98.7 & 1.20 & 1646 Valyaev et al. (1985) \\
\hline Shikhikaya & -47.3 & -170 & -36.9 & 98.9 & 0.99 & 989 Valyaev et al. (1985) \\
\hline Shikhzagirli (Ilanly) & -42.5 & -194 & +0.1 & 99.1 & 0.81 & 3302 Valyaev et al. (1985) \\
\hline Shokikhan & -42.0 & -228 & +13.8 & 96.7 & 3.30 & 3222 Valyaev et al. (1985) \\
\hline Zayachya Gora (a) & -44.8 & -198 & +10.5 & 99.0 & 0.81 & 1647 Valyaev et al. (1985) \\
\hline Zaakhtarma & -46.0 & -220 & +14.1 & 93.8 & 6.14 & 852 Valyaev et al. (1985) \\
\hline \multicolumn{7}{|l|}{ China } \\
\hline site 1 & -45.9 & -229 & -8.0 & 91.6 & 0.20 & 11 Nakada et al. (2011) \\
\hline site 2 & -43.7 & -244 & +16.2 & 89.0 & 0.50 & 9 Nakada et al. (2011) \\
\hline site 4 & -42.4 & -227 & -11.5 & 89.6 & 0.10 & 10 Nakada et al. (2011) \\
\hline site 6 & -40.7 & -252 & +21.1 & 81.5 & 0.14 & 15 Nakada et al. (2011) \\
\hline site 7 & -39.7 & -264 & +24.6 & 80.4 & 0.17 & 13 Nakada et al. (2011) \\
\hline site 8 & -40.7 & -229 & +29.8 & 92.6 & 0.45 & 14 Nakada et al. (2011) \\
\hline site 9 & -38.6 & -242 & -4.8 & 75.8 & 0.31 & 9 Nakada et al. (2011) \\
\hline \multicolumn{7}{|l|}{ Georgia } \\
\hline Tyulkitapa & -53.1 & -196 & +5.9 & 89.0 & 10.86 & 77 Valyaev et al. (1985) \\
\hline \multicolumn{7}{|l|}{ Japan } \\
\hline Kamou & -33.9 & -172 & +10.9 & 95.4 & 2.91 & 108 Etiope et al. (2011) \\
\hline Murono vent2 & -36.2 & -175 & +28.3 & 93.7 & 5.62 & 144 Etiope et al. (2011) \\
\hline \multicolumn{7}{|l|}{ Turkmenistan } \\
\hline Keimir & -48.2 & -213 & -25.2 & 95.3 & 0.89 & 79 Valyaev et al. (1985) \\
\hline Kipyashii Bugor & -43.8 & -176 & +6.9 & 96.8 & 2.79 & 968 Valyaev et al. (1985) \\
\hline Ak-Patlauk & -55.7 & -199 & -16.2 & 94.2 & 3.67 & 44 Valyaev et al. (1985) \\
\hline
\end{tabular}

Table 1. Selected data of composition and stable isotope ratio of $\mathrm{CH}_{4}$ and $\mathrm{CO}_{2}$.

3 were not collected). Another example can be given by mud volcanoes in Japan. Kato et al. (2009) reported that the $\delta^{13} \mathrm{C} \mathrm{CO} 2$ value of gas released from the Murono mud volcano in August 2004 was $+30.8 \%$. Mizobe (2007) showed that the value of the same mud volcano in May 2005 was $+19.2 \%$ and in June 2006 was $+21.2 \%$. Etiope et al. (2011) reported the value of the same mud volcano was $+28.32 \%$ in May 2010. In contrast, the variation observed in $\delta^{13} \mathrm{C}_{1}$ value of the Murono mud volcano reported in these papers was $-33.1 \%$ o to $-36.2 \%$. These observations mean that the different vents of a mud volcano can be related to different circulation systems and/or post-genetic processes, and possibly different source pools or reservoirs. Some of the large Azerbaijan mud volcanoes show oil-saturated structures in some vents while others do not. This finding means that mud volcano systems may not be uniform, but can be structured in different systems and isolated blocks. 
However, the variation of $\delta^{13} \mathrm{C} \mathrm{CO}_{2}$ with time for the same vent suggests that $\mathrm{CO}_{2}$ carbon isotopes are intrinsically unstable and can be affected by multiple gas-water-rock interactions. According to the estimation by Pallasser (2000), however, the dissolution effect is limited in the carbon isotope enrichments of up to $5 \%$, suggesting that the main enrichment is due to biochemical fractionation related to secondary methanogenesis.

Figure 3 shows that ${ }^{13} \mathrm{C}$-enriched $\mathrm{CO}_{2}$ has no relation with $\mathrm{CO}_{2}$ concentrations. Hypothetical end-members were assumed in the figure at $30 \% \mathrm{CO}_{2}$ with a carbon isotope ratio of $10 \%$ and $25 \% \mathrm{CO}_{2}$ with $\delta^{13} \mathrm{C} \mathrm{CO}_{2}$ of $30 \%$ for fermentation of hydrocarbon oxidation products, and $0 \% \mathrm{CO}_{2}$ with carbon isotope ratio of $-20 \%$ and $0.5 \% \mathrm{CO}_{2}$ with $\delta^{13} \mathrm{CCO}_{2}$ of $0 \%$ o for thermogenic (Jeffrey et al., 1991). The observed data are distributed following the mixing trend between $\mathrm{CO}_{2}$-rich gas produced by fermentation and $\mathrm{CO}_{2}$-poor thermogenic gas. The two trend lines appear compatible with a mixing model and, therefore, with the presence of a residual $\mathrm{CO}_{2}$ related to secondary methanogenesis and anaerobic biodegradation.

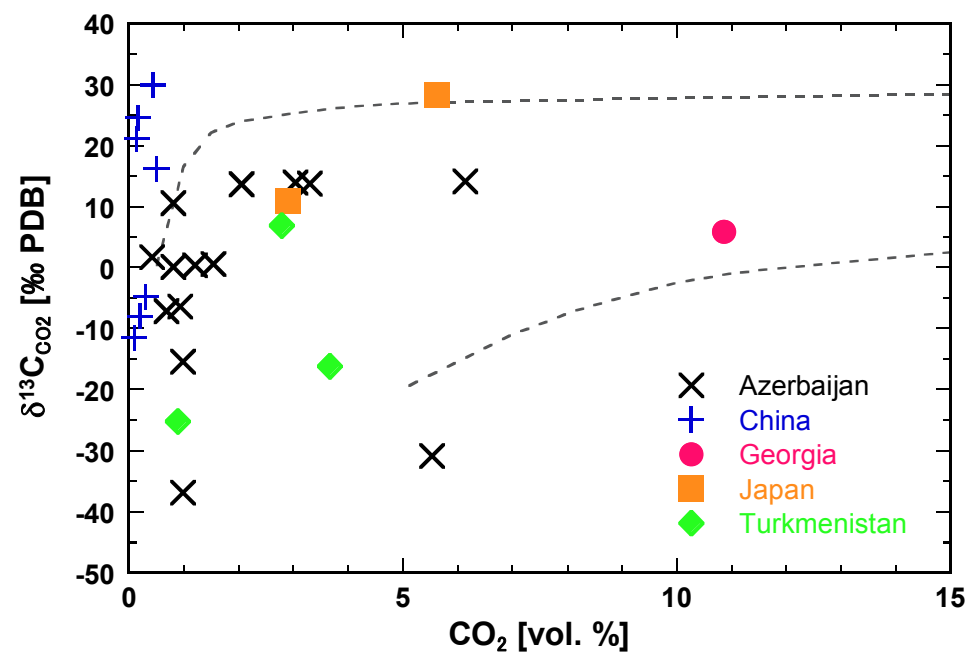

Figure 3. Relationship between $\delta^{13} \mathrm{CCO}_{2}$ and $\mathrm{CO}_{2}$ concentration. The 2 lines refer to a mixing trend similar to the model by Jeffrey et al. (1991).

\section{3. $\mathrm{CH}_{4}$ versus $\mathrm{CO}_{2}$}

The relationship between $\delta^{13} \mathrm{C}$ of $\mathrm{CH}_{4}$ and $\mathrm{CO}_{2}$ is shown in Fig. 4. The ${ }^{13} \mathrm{C}$-enriched $\mathrm{CO}_{2}$ seems to occur preferentially in thermogenic $\mathrm{CH}_{4}$, where $\delta^{13} \mathrm{C}_{1}$ values are within a range of $50 \%$ o to $-30 \%$. In other words, this relationship seems to have a correlation; the gases showing a low $\delta^{13} \mathrm{C}_{1}$ value have a low $\delta^{13} \mathrm{CCO}_{2}$ value while a high $\delta^{13} \mathrm{C}_{1}$ value corresponds to a high $\delta^{13} \mathrm{C} C O 2$ value. This observation can imply that the light $\delta^{13} \mathrm{C}_{1}$ in the few mud volcanoes (although data are not shown here, gases from Azerbaijan, Italy, Papua New Guinea, and Taman Peninsula fall in the microbial area in the Bernard diagram) with microbial gas is not due to secondary methanogenesis, but simply to primary methanogenesis. On the other 
hand, thermogenic gas with ${ }^{13} \mathrm{C}$-enriched $\mathrm{CO}_{2}$ maintains its high $\delta^{13} \mathrm{C}_{1}$ value, indicating that $\delta^{13} \mathrm{C}_{1}$ value is not perturbed by the secondary microbial gas. The $\delta^{13} \mathrm{C}_{1}$ value does not vary to a large degree by post-genetic alteration because the amount of secondary microbial $\mathrm{CH}_{4}$ is small compared with that of the pre-existing thermogenic gas.



Figure 4. Relationship between carbon isotopes of $\mathrm{CH}_{4}$ and $\mathrm{CO}_{2}$.

However, the post-genetic alteration can lead to a significant change in their concentration and isotopic composition for $\mathrm{CO}_{2}$. Oil biodegradation, one of the post-genetic alterations followed by $\mathrm{CO}_{2}$ reduction, is described as follows:

$$
\mathrm{CO}_{2}+4 \mathrm{H}_{2} \rightarrow \mathrm{CH}_{4}+2 \mathrm{H}_{2} \mathrm{O} .
$$

This reaction is associated with a large kinetic isotope effect, meaning that the more the reaction proceeds with decreasing $\mathrm{CO}_{2}$ concentration, the more ${ }^{13} \mathrm{C}$ is enriched in residual $\mathrm{CO}_{2}$. Considering that $\mathrm{CO}_{2}$ is a minor component of gases released from mud volcanoes, the concentration and isotopic composition of $\mathrm{CO}_{2}$ can largely be affected by the reaction. The isotope effect of oil biodegradation results in the increase in $\delta^{13} \mathrm{C}$ of residual $\mathrm{CO}_{2}$, which can easily exceed $+10 \%$ (Pallasser, 2000; Waseda and Iwano, 2008). Occurrence of oil biodegradation is suggested by the high $\mathrm{C}_{2} / \mathrm{C}_{3}$ and i- $\mathrm{C}_{4} / \mathrm{n}-\mathrm{C}_{4}$ ratios (Pallasser, 2000; Waseda and Iwano, 2008) and/or by the presence of $\mathrm{H}_{2}$ gas. For example, all these characteristics are identified in the gases released from mud volcanoes in China, which show a large variation in $\delta^{13} \mathrm{C}_{\mathrm{CO} 2}$ as described above (Nakada et al., 2011). The increase of $\mathrm{C}_{2} / \mathrm{C}_{3}$ ratio due to oil biodegradation also leads to an increase of Bernard ratio, meaning that a gas sample plotted 
on the Bernard diagram will move in an upward direction. Thus, gases that fall in region A, which is geometrically above the thermogenic field in the Bernard diagram (Fig. 1), can be subject to the post-genetic alteration including biodegradation.

\subsection{Depth of the reservoir and ${ }^{13} \mathrm{C}$-enriched $\mathrm{CO}_{2}$}

The anaerobic biodegradation of oil and natural gas has been document to be mostly limited to shallow reservoirs, generally shallower than $2000 \mathrm{~m}$ with temperature below $60{ }^{\circ} \mathrm{C}$ to 80 ${ }^{\circ} \mathrm{C}$ (Pallasser, 2000; Feyzullayev and Movsumova, 2001). For example, the depth of petroleum reservoirs in the South Caspian Basin is shallower than $2000 \mathrm{~m}$ if the data are confined to the gas showing ${ }^{13} \mathrm{C}$-enriched $\mathrm{CO}_{2}$ (Fig. 5; after Etiope et al., 2009). This observation suggests that mud volcanoes showing anaerobic biodegradation signals will be linked with shallow reservoirs, while mud volcanoes without anaerobic biodegradation will more likely be produced by deeper reservoirs. Anaerobic biodegradation of petroleum and subsequent secondary methanogenesis, however, can also take place at shallower depths even above the deep reservoir along the seepage channels of the mud volcano system.



Figure 5. Carbon isotopic ratios of $\mathrm{CO}_{2}$ vs. reservoir depth in the South Caspian Basin and China. 
Recently, Nakada et al. (2011) showed that the reservoir depth of mud volcanoes in Xinjiang Province, China, is deeper than $3600 \mathrm{~m}$, though some of the volcanoes release ${ }^{13} \mathrm{C}$-enriched $\mathrm{CO}_{2}$. The province hosts a large abundance of petroleum; therefore, many oil-testing wells are made in the province, leading to the knowledge of geothermal gradient and depth of oil reservoir. Nakada et al. (2011) calculated the equilibrium temperature of oxygen isotope fractionation between water and calcite in mud, indicating that the temperature where the water-rock interaction is occurring is $81{ }^{\circ} \mathrm{C}$ for mud volcanoes located close to the Dushanzi oil field. Assuming the mean geothermal gradient of the area is $18 \pm 1{ }^{\circ} \mathrm{C} / \mathrm{km}$ (Nansheng et al., 2008) and that the surface temperature is $15^{\circ} \mathrm{C}$, the depth of the chamber with the temperature of $81{ }^{\circ} \mathrm{C}$ is calculated to be $3670 \pm 200 \mathrm{~m}$. The calculated depth is slightly deeper than the oil reservoir at the Dushanzi field (3644 m-3656 m; Clayton et al., 1997). However, considering that the reservoir of saline fossil waters related to petroleum is generally deeper than that of oil and gas due to the difference in density, the calculation by Nakada et al. (2011) was surprisingly well consistent with the observation by Calyton et al. (1997). Then, Nakada et al. (2011) estimated the depth of gas reservoir at about $3600 \mathrm{~m}$ by considering that (i) the gases released from the mud volcanoes in the area were thermogenic gas associated with oil and (ii) the gas reservoir is generally located above the petroleum reservoir. The depth of 3600 $\mathrm{m}$ is greater than those previously reported for mud volcanoes releasing ${ }^{13} \mathrm{C}$-enriched $\mathrm{CO}_{2}$, such as those in South Caspian Basin. Thus, the secondary microbial effect that can occur at a relatively shallower depth must be considered separately from the initial thermogenic source in the field in China. Therefore, Nakada et al. (2011) clearly showed that the anaerobic biodegradation of petroleum can take place at a shallower depth. This result strengthens the model that considers a deep reservoir with thermogenic gas and secondary microbial activity occurring along the seepage system above the main deep reservoir.

\section{Summary}

Terrestrial mud volcanoes release a dominant abundance of thermogenic $\mathrm{CH}_{4}$ related to the activities in relatively deep reservoirs, most of which are in petroleum seepage systems. Maturated petroleum associated with gas and water pressurizes the reservoir, causing gas and water to ascend preferentially through faults (Nakada et al., 2011). Some post-genetic secondary processes can alter the chemical and isotopic composition of the gases. Among these processes, some mixing, molecular fractionation, and particularly, secondary methanogenesis related to subsurface biodegradation of petroleum seem to be significant in changing the chemical and isotopic composition of gases released from mud volcanoes. Mud volcanoes show highly variable $\delta^{13} \mathrm{C} \mathrm{CO}_{2}$ values even within the same mud volcanoes, such that ${ }^{13} \mathrm{C}$-enriched $\mathrm{CO}_{2}$ can be found in some vents and not in others nearby, or not systematically changed in the same vent, meaning that ${ }^{13} \mathrm{C}$-enriched $\mathrm{CO}_{2}$ is, therefore, not an uncommon characteristic. The association of anaerobic biodegradation can depend on the type of microbial communities and physicochemical conditions of the reservoir. 


\section{Author details}

Ryoichi Nakada* and Yoshio Takahashi

Department of Earth and Planetary Systems Science, Graduate School of Science, Hiroshima University, Higashi-Hiroshima, Hiroshima, Japan

\section{Acknowledgement}

R. N. is a Research Fellow of the Japan Society of the Promotion of Science. We thank Prof. Guodong Zheng (Chinese Academy of Sciences) for his suggestions throughout this study.

\section{References}

Baylis, S.A., Cawley, S.J., Clayton, C.J., Savell, M.A. (1997) The origin of unusual gas seeps from onshore Papua New Guinea. Mar. Geol., 137, 109-120.

Bernard, B.B., Brooks, J.M., Sackett, W.M. (1978) Light hydrocarbons in recent Texas continental shelf and slope sediments. J. Geophys. Res., 83, 4053-4061.

Capozzi, R., Picotti, V. (2002) Fluid migration and origin of a mud volcano in the Northern Apennines (Italy): the role of deeply rooted normal faults. Terranova, 14, 363-370.

Clayton, J. L., Yang, J., King, J. D., Lillis, P. G., and Warden, A. (1997) Geochemistry of oils from the Junggar Basin, Northwest China. AAPG Bull., 81, 1926-1944.

Deville, E., Battani, A., Griboulard, R., Guerlais, S.H., Herbin, J.P., Houzay, J.P., Muller, C., Prinzhofer, A. (2003) Mud volcanism origin and processes. New insights from Trinidad and the Barbados Prism. In: Van Rensbergen, P., Hillis, R.R., Maltman, A.J., Morley, C. (Eds.), Surface Sediment Mobilization. Special Publication of the Geological Society (London), vol. 216, pp. 475-490.

Dimitrov, L. I. (2002) Mud volcanoes-the most important pathway for degassing deeply buried sediments. Earth-Sci. Rev., 59, 49-76.

Dimitrov, L. I. (2003) Mud volcanoes-a significant source of atmospheric methane. Geo-Mar. Lett., 23, 155-161.

Etiope, G. and Klusman, R. W. (2002) Geologic emissions of methane to the atmosphere. Chemosphere, 49, 777-789.

Etiope, G. and Milkov, A. V. (2004) A new estimate of global methane flux from onshore and shallow submarine mud volcanoes to the atmosphere. Environ. Geol., 46, 997-1002.

Etiope, G., Papatheodorou, G., Christodoulou, D., Ferentinos, G., Sokos, E., Favali, P. (2006) Methane and hydrogen sulfide seepage in the NW Peloponnesus petroliferous basin (Greece): origin and geohazard. AAPG Bull., 90, 701-713.

Etiope, G., Martinelli, G., Caracausi, A., Italiano. F. (2007) Methane seeps and mud volcanoes in Italy: gas origin, fractionation and emission to the atmosphere. Geophys. Res. Lett., 34, L14303.

${ }^{*}$ Corresponding Author 
Etiope, G., Feyzullayev, A., Milkov, A. V., Waseda, A., Mizobe, K. and Sun, C. H. (2009) Evidence of subsurface anaerobic biodegradation of hydrocarbons and potential secondary methanogenesis in terrestrial mud volcanoes. Mar. Pet. Geol., 26, 1692-1703.

Etiope, G., Nakada, R., Tanaka, K., and Yoshida, N. (2011) Gas seepage from Tokamachi mud volcanoes, onshore Niigata Basin (Japan): Origin, post-genetic alterations and $\mathrm{CH}_{4}-\mathrm{CO}_{2}$ fluxes. Appl. Geochem., 26, 348-359.

Faber, E., Stahl, W. (1984) Geochemical surface exploration for hydrocarbons in the North Sea. AAPG Bull., 68, 363-386.

Favara, R., Gioia, C., Grassa, F., Inguaggiato, S., Proietto, F., Valenza, M. (2001) Studio geochimico delle manifestazioni fluide della riserva naturale integrale "Macalube di Aragona". Nat. Sicil., 25, 137-154 (in Italian).

Feyzullayev, A. and Movsumova, U. (2001) About the origin of isotopically heavy $\mathrm{CO}_{2}$ in gases of Azerbaijan mud volcanoes. Azerb. Geol., 6, 96-105 (in Russian).

Greber, E., Leu, W., Bernoulli, D., Schumacher, M.E., Wyss, R. (1997) Hydrocarbon provinces in the Swiss southern Alps-a gas geochemistry and basin modeling study. Mar. Pet. Geol., 14, 3-25.

Hosgormez, H., Etiope, G., and Yalçin, M. N. (2008) New evidence for a mixed inorganic and organic origin of the Olympic Chimaera fire (Turkey): a large onshore seepage of abiogenic gas. Geofluids, 8, 263-273.

Intergovernmental Panel on Climate Change (2001) Houghton, J.T., Ding, Y., Griss, D.J., Noguer, M., van der Linden, P.J., Dai, X., Maskell, K., Johnson, C.A. (Eds), Climate Change 2001: The scientific basis. Cambridge Univ PressCambridge, UK, pp. 881

Jeffrey, A.W.A., Alimi, H.M., Jenden, P.D. (1991) Geochemistry of the Los Angeles Basin oil and gas systems. In: Biddle, K.T. (Ed.), Active Margin Basins. AAPG Memoir, vol. 52, pp. 197-219.

Jenden, P. D., Hilton, D. R., Kaplan, I. R., Craig, H. (1993) Abiogenic hydrocarbons and mantle helium in oil and gas fields. In: Howell, D. (Ed.), The Future of Energy Gases, vol. 1570. USGS, pp. 31-35.

Kato, S., Waseda, A., Nishita, H., Iwano, H. (2009) Geochemistry of crude oils and gases from mud volcanoes and their vicinities in the Higashi-Kubiki area, Niigata Prefecture. Journal of Geography, 118, 455-471 (In Japanese with English abstract).

Kholodov, V. N. (2002) Mud volcanoes, their distribution regularities and genesis: communication 1. mud volcanic provinces and morphology of mud volcanoes. Lithol. Miner. Resour., 37, 197-209.

Kopf, A. J. (2002) Significance of mud volcanism. Rev. Geophys., 40, 1-52.

Kotarba, M. J. (2001) Composition and origin of coalbed gases in the Upper Silesian and Lublin basins, Poland. Org. Geochem., 32, 163-180.

Lavrushin, V. Y., Polyak, B. G., Prasolov, R. M. and Kamenskii, I. L. (1996) Sources of material in mud volcano products (based on isotopic, hydrochemical, and geological data). Lithol. Miner. Resour., 31, 557-578.

Mazzini, A., Svensen, H., Akhmanov, G. G., Aloisi, G., Planke, S., Malthe-Sørenssen, A., and Istadi, B. (2007) Triggering and dynamic evolution of the LUSI mud volcano, Indonesia. Earth Planet. Sci. Lett., 261, 375-388. 
Mizobe, K. (2007) Geochemical characteristics of natural gases from mud volcanoes in Tokamachi City, Niigata Prefecture. Master Thesis, Graduate School of Science and Engineering, Yamaguchi University, pp. 44.

Nakada, R., Takahashi, Y., Tsunogai, U., Zheng, G., Shimizu, H., and Hattori, K. H. (2011) A geochemical study on mud volcanoes in the Junggar Basin, China. Appl. Geochem., 26, 1065-1076.

Nansheng, Q., Zhihuan, Z. and Ershe, X. (2008) Geothermal regime and Jurassic source rock maturity of the Junggar Basin, northwest China. J. Asian Earth Sci., 31, 464-478.

Pallasser, R. J. (2000) Recognising biodegradation in gas/oil accumulations through the $\delta^{13} \mathrm{C}$ compositions of gas components. Org. Geochem., 31, 1363-1373.

Schoell, M. (1983) Genetic characterization of natural gases. AAPG Bull., 67, 2225-2238.

Valyaev, B.M., Grinchenko, Y.I., Erokhin, V.E., Prokhorov, V.S., Titkov, G.A. (1985) Isotopic composition of gases from mud volcanoes. Lithol. Miner. Resour., 20, 62-75.

Waseda, A., Iwano, H. (2008). Characterization of natural gases in Japan based on molecular and carbon isotope compositions. Geofluids, 8, 286-292. 